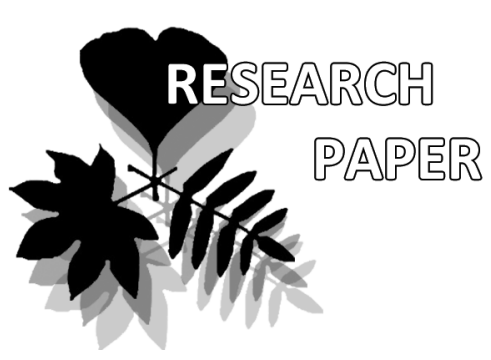

Cezary Toma

e-mail: cezarytoma@poczta.onet.pl

Department of Carpology, Kazimierz Wielki University, Bydgoszcz, Poland

Manuscript received: 29.11 .2018 Review completed: 26.06.2019

Accepted for publication: 25.10.2019

Published online: 06.11.2019

\section{Phenotypic plasticity of Stratiotes aloides L. (Hydrocharitaceae)}

\author{
Cezary'Toma
}

\begin{abstract}
A B S T R A C T
The purpose of the research was to determine the diversity of Stratiotes aloides L. specimens in lake populations. The research material was collected from 6 Polish lakes and from five depths in each lake. A total of 19 qualitative and quantitative features of $S$. aloides were examined. The modified Shannon-Wiener index of $S$. alo$i d e s$ for six lakes and the analysed means, minimums and maximums were calculated, ANOVA analysis of variance for 6 lakes and 5 depths, the percentage increase for specimens between various levels was calculated, PCA analysis was performed, and the correlations between the examined features were discovered. $S$. aloides in Polish lake populations demonstrates high and very high diversity, which was confirmed by the overlapping scopes of quantitative features at individual depths and different values of quantitative features at the same depths in different lakes. $S$. aloides forms specimens with various numbers of emergent, submerged and arched leaves, depending on the degree of the specimen immersion in water. $S$. aloides have been found to have the smallest variation coefficient at depth 1-2 m. At any other depth, the variation coefficient is greater. Changing the depth results in increased coefficient variation. It is also disclosed that emergent leaves appear at level 0.5-1 $\mathrm{m}$, while leaves that form deeper are submerged leaves. Studies have shown that lake populations of Stratiotes aloides form individuals with different numbers of emergent and submergent leaves, and not only in two forms or three ecophenes. Stratiotes aloides exhibits continuous plasticity.
\end{abstract}

K e y w o r d s : water plant, emergent form, submergent form, diversity, polymorphism

\section{P E 3 Ю M E}

Тома Ц. Фенотипическая пластичность Stratiotes aloides L. (Hydrocharitaceae). Целью исследования было определение разнообразия образцов Stratiotes aloides L. в популяциях озер. Материал был собран из 6 озер в Польше с пяти глубин в каждом озере. Всего исследовано 19 качественных и количественных признаков $S$. aloides. А^я шести озер были рассчитаны среАние, минимальные и максимальные параметры S. aloides. Аанные были проанализированы с помощью модифицированного индекса Шеннона-Винера, ANOVA и PCA. Между изученными признаками были обнаружены корреляции. $S$. aloides в озерных популяциях демонстрирует большое и очень высокое разнообразие, что подтверждается перекрывающимися областями количественных признаков на отдельных глубинах и различными значениями количественных признаков на одинаковых глубинах в разных озерах. S. aloides образует морфотипы с различным количеством всплывающих, погруженных и Аугообразных мистьев в зависимости от степени погружения растения в воду. Установлено, что $S$. aloides имеет наименьший коэффициент вариации на глубине 1-2 м. На Аюбой Аругой глубине коэффициент вариации больше. Изменение глубины приводит к увеличению коэффициента вариации. Также обнаружено, что надводные мистья у растений фор-

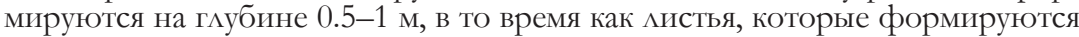
глубже, остаются погруженными. Исследования показали, что озерная популяция $S$. aloides формируется из особей с разным числом надводных и

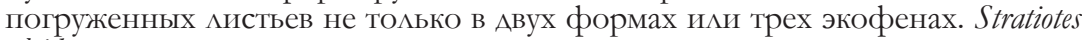
aloides прояв яет непрерывную пластичность.

Ключевые слова: водные растения, надводная форма, подводная форма, разнообразие, полиморфизм
Stratiotes aloides L., an aquatic plant, belongs to the family Hydrocharitaceae Juss. This submerged aquatic plant is native to Europe and Northwestern Asia (Cook \& Urmi-Kőnig 1983). In Poland, S. aloides L. blooms and fruits (Madalski 1938, Toma 2001). Previous reports concerned the fructification (Smolders 1995a, 1995b), the vegetative propagation and the ecology of the $S$. aloides (Glück 1936, Kor- natowski 1976, 1979, 1983/84, 1985, Renman 1989, Strzałek 2004, Efremov 2016).

S. aloides is commonly found in aquatic environments in two forms: emergent forms with rigid leaves and submerged forms with undulated and arched leaves (Toma 2006, Efremov \& Sviridenko 2008). This plant is found in lakes, ponds, old river beds and in overgrown forest waterholes. $S$. aloides 
lake populations are composed of the most diverse plants with high plasticity, that was observed before the research commenced.

Kornatowski (1985) recognized three ecophenes or phases of phenotypic modification within the shapely form of $S$. aloides: early emergent, late emergent and submergent, and noted that biometric differences between these ecophenes were smaller within a particular lake than within a single ecophene present in several water bodies.

$S$. aloides is a species with a changeable number of chromosomes: $2 \mathrm{n}=24$ (Schürhoff 1926), 40 (Negodi 1929), 48 (Gadella \& Kliphois 1973, Letz et al 1999; Orsenigo et al. 2017). In S. aloides, the medium and high values of genetic diversity was discovered at population level, as well as the occurrence of three genetic patterns identifiable in the central-western, central and eastern Europe-Asian populations of $S$. aloides. The similarity between populations belonging to different hydrographical basins, and the differences between neighbouring populations could be explained through long-distance bird-mediated dispersal events (Orsenigo et al. 2017). In some areas, S. aloides is an invasive plant (Snyder et al 2016, Swearingen \& Bargeron 2016).

To accurately determine patterns of plasticity and investigate the ecological and evolutionary implications, it is important to better understand the environmental context in which phenotypes are expressed (Sultan 2004). Moczek (2015) emphasises the role of research on plasticity as a development standard. The following gaps in present studies have been indicated: 1) the plasticity and sizes of emergent and submerged forms of $S$. aloides have not been examined; 2) the existing researches are fragmentary, and they fail to confirm the continuous plasticity of $S$. aloides; 3) the depth of the water in which specimens start to form emergent leaves is unknown; 4) the changeability of morphological characteristics of specimens at different depths of water, as well as changeability indices are not known.

The purpose of the research is to determine the diversity of S. aloides plants in lake populations. In particular, to determine the variability of the specimen size at different immersion levels, to determine the quantity of emergent and submerged forms at different depths, to determine the number of generative organs, to determine the changeability indices of leaves at different depths and in different lakes, and to determine the depth of the lakes were emergent leaves can be found.

\section{MATERIAL AND METHODS}

The research was conducted in northern Poland, at the lakes of Bytowskie Lakeland in the period between 2013 and 2016. Lake no. 1 (53 $\left.52.0^{\prime} \mathrm{N} 16^{\circ} 39.6^{\prime} \mathrm{E}\right)$, Lake no. 2 $\left(53^{\circ} 55.0^{\prime} \mathrm{N} 17^{\circ} 03.5^{\prime} \mathrm{E}\right)$, Lake no. $3\left(53^{\circ} 56.3^{\prime} \mathrm{N}, 17^{\circ} 00.0^{\prime} \mathrm{E}\right)$,
Lake no. $4\left(53^{\circ} 55.8^{\prime} \mathrm{N}, 16^{\circ} 49.3^{\prime} \mathrm{E}\right)$, Lake no. $5\left(53^{\circ} 58.3^{\prime} \mathrm{N}\right.$ $\left.17^{\circ} 04.5^{\prime} \mathrm{E}\right)$, Lake no. $6\left(53^{\circ} 56.5^{\prime} \mathrm{N} 17^{\circ} 14.0^{\prime} \mathrm{E}\right)$ (Table 1).

Specimens of $S$. aloides were collected from a boat or a pontoon with the use of a 4.5-meter long calibrated rake. The lakes were floated around and a stretch of water from the lake shore up to 20 meters into the lake was monitored. After preliminary observations, the levels from which specimens were to be collected were determined. These are the following depth: 1) water surface to a depth of 0.5 meters, 2) the depth from 0.5 meters to 1 meter, 3) the depth from 1 meter to 2 meters, 4) the depth from 2 meters to 3 meters and 5) the depth from 3 meters to 4 meters. The specimen immersion level was determined by the depth of the arrangement of the bottom part of the rosette from which leaves and roots grow. 30 individuals were collected from each depth, and 150 individuals from each lake. Specimens were taken out of water and their features were observed; the obtained data is entered into research sheets. The total of 19 qualitative and quantitative features were examined (Table 2). In order to determine the specimen plasticity diversity, a modified Shannon-Wiener index $(\mathrm{H})$ was applied. Designations in the formula determining the diversity of specimens in the conducted research, thus including plasticity of $S$. aloides for the lake, are as follows: HPT $=-\sum p_{i}^{*} \log p_{i}$, where $p_{i}=n_{i} / N_{i} n_{i}-$ the number of specimens with a particular feature, $N_{i}$ - the number of all specimens with all the features. The data was analysed with the use of the computer programmes Statistica 12 and Exel.

\section{RES ULT S}

The total of 900 S. aloides specimens and 35738 leaves were examined. $S$. aloides specimen diversity indices (HPT) for the lakes demonstrate great differences between them (Fig. 1), which confirms the considerable adaptability of water soldiers to the changeable conditions of their aquatic environment and the capability of creating a whole spectrum of transitory forms. The obtained result clearly indicates the presence of a smaller diversity of $S$. aloides specimens in lakes no. 1, 2, 5 and 6, a higher diversity in lake no. 4, and a very high diversity in lake no. 3 (Fig. 1).

The results for the variable of submerged leaves occurrence indicate that $S$. aloides started to increase on the water surface and the emergent form grew, but not on every examined lake. It is worth adding, that for other lakes, there are differences in the number of emergent leaves, and for other lakes there are differences in the number of submerged leaves. Therefore, the production of submerged and emergent leaves is also highly diverse. There were also S. aloides specimens found that had different types of leaves. Transitional forms, which had submerged, undulated, light

Table 1. Parameters of the studied lakes in the Bytowskie Lake District in Poland (Jańczak 1996).

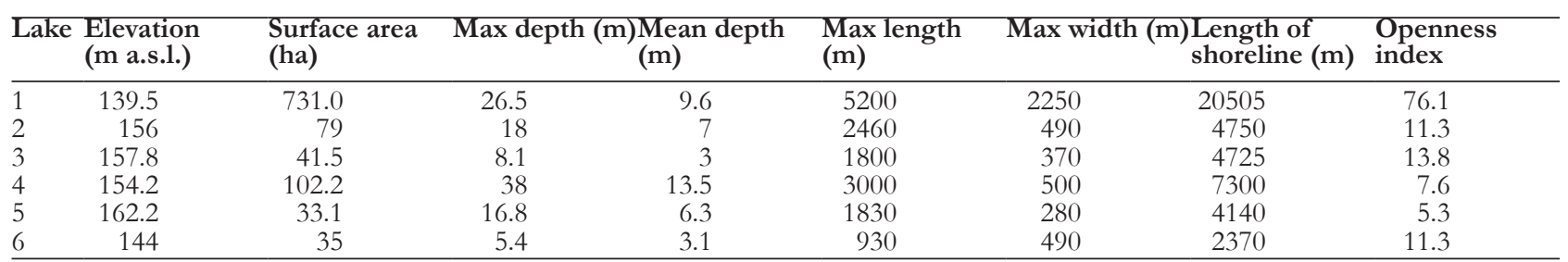


green leaves and rigid dark green emergent leaves were particularly interesting. The process of the creation of emergent leaves in the examined specimens starts under the water surface. Further in the analyses, the depth of the water was determined at which emergent leaves were produced.

The occurrence of fruits in $S$. aloides was confirmed only above the water surface. There was only one case found of a submerged $S$. aloides form which was in bloom, and its flower was located about $30 \mathrm{~cm}$ under the water surface. It is difficult to say what the reason was for that - whether there was a sudden increase in the water surface level or some other cause. This case was not taken into account in the statistics.

The ANOVA analysis of variance for 6 lakes showed significant differences among all traits except the occurence of male $S$. aloides specimens, the occurence of buds and flowers. ANOVA analysis of variance was also made for the examined traits between depth levels 1 to 5 . There are significant differences between the depth for the variables.

The mean, minimum and maximum numbers of fruit, turions, emergent leaves, submerged leaves, arched leaves, and the length and width of specimens for individual depths and lakes were calculated. The results for levels (Figs $2 \mathrm{~A}-\mathrm{H}$ ) and lakes (Figs $3 \mathrm{~A}-\mathrm{H}$ ) are presented on box plots.

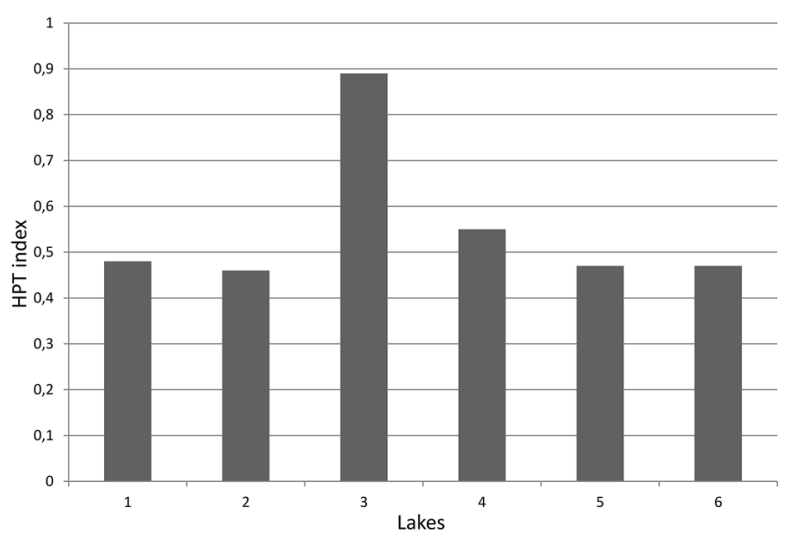

Figure 1 Comparison of the variation of index HPT of Stratiotes aloides L. in 6 lakes

Table 2. List of studied Stratiotes aloides features and their abbreviations.

\begin{tabular}{lll}
\hline L.p. & Features & Abbreviation \\
\hline 1 & Occurrence of emergent leaves & EL \\
2 & Occurence of submerged leaves & SL \\
3 & Occurrence arched submerged leaves & AL \\
4 & Occurence of mixed leaves & ML \\
5 & Male individuals & MI \\
6 & Female individuals & EI \\
7 & Individuals with gender unspecified & UI \\
8 & Occurrence of generative organs & GO \\
9 & Occurence of generative organs above & GS \\
10 & the water surface & FN \\
11 & Fud number & FRN \\
12 & Fruit number number & TN \\
13 & Turion number & LI \\
14 & Lenght of individuals & WI \\
15 & Width of individuals & NEL \\
16 & Nuber of emergent leaves & NSL \\
17 & Number of submerged leaves & TNL \\
18 & Number of arched submerged leaves & LLR \\
19 & Total number of leaves & \\
\hline
\end{tabular}

Among the examined variables, the length and widths of $S$. aloides specimens have the largest standard deviation at all depth levels. The smallest mean and the smallest standard deviation have the following variables: number of fruit and number of turions at all levels. The maximum value of a mean for the variable number of emergent leaves is at a level of 1 , then it drops, and emergent leaves disappear from level 2. An important observation is the fact that the occurrence of emergent and submerged form together only at level 1 and 2. From level 3 upwards, there are no emergent leaves. Therefore, level 2 is the place where new leaves are created that become emergent leaves (Fig. 2E).

In lakes, the largest standard deviations are for the length and width variables of specimens, and for emergent leaves, the standard deviation is smaller than for submerged leaves. Standard deviations of the total number of leaves in specimens are smaller in lakes 1 and 3 , and larger and comparable between lakes 2, 4, 5 and 6 (Figs 3A-H).

The analysis of means for the length and width variables of a specimen, the number of fruit and turions, emergent leaves, and submerged arched leaves for the levels in individual lakes were conducted. $S$. aloides demonstrates different means for features at the same levels in different lakes. In lake $1, S$. aloides specimens increase the mean length by $24 \%$ and width by $26 \%$ from level 1 to level 3 . At no level do the specimens have arched leaves, and turions can be found in specimens at levels 1, 2 and 3. In lake no. 2, specimens decrease their mean length by $29 \%$ and width by $45 \%$ from level 3 to level 5 . Arched leaves can be found in specimens at level 5, and turions in specimens at level 3. In lake no. 3, specimens have their largest mean length and width at levels 2, 3 and 4, and they are smaller at levels 1 and 2. Arched leaves can be found in specimens at levels 2, 3 and 4 , and turions in specimens at level 1 and 2 . In lake no. 4 , there is an increase in length by $27 \%$ and width by $39 \%$ from level 1 to level 3.

The increase in the total number of leaves is from 1 to 3. There are no arched leaves, and turions can be found in specimens at level 1, 2 and 3. In lake no. 5, on average, the largest specimens can be found at level 3. Their length and width decrease both up to level 2 and down to level 4. Arched leaves can be found at level 3, and turions at level 2, 3 and 4 . In lake no. 6, one can observe an increase in S. aloides specimen length by $134 \%$ and width by $150 \%$ within the range from level 1 to level 4 . The deeper they are, the larger the specimens become. Arched leaves can be found only at level 1, and turions can be found at level 1, 3 and 4 .

Principal Component Analysis (PCA) was performed in order to explain which variables are responsible for high plasticity and what are the regularities between them (Fig. 4). Due to the fact that some features are specified in centimetres and some in abstract numbers, a correlation matrix was created. The characteristic value for the first component is 5.004 , and the percentage of the variances it explains amounts to 62.55 . The second component has a characteristic value of 2.55 and explains $31.89 \%$ of variances. Therefore, the two first components explain $94.45 \%$ of variances. On the scree plot, the downward line transforms into a horizontal line only at the third component. 

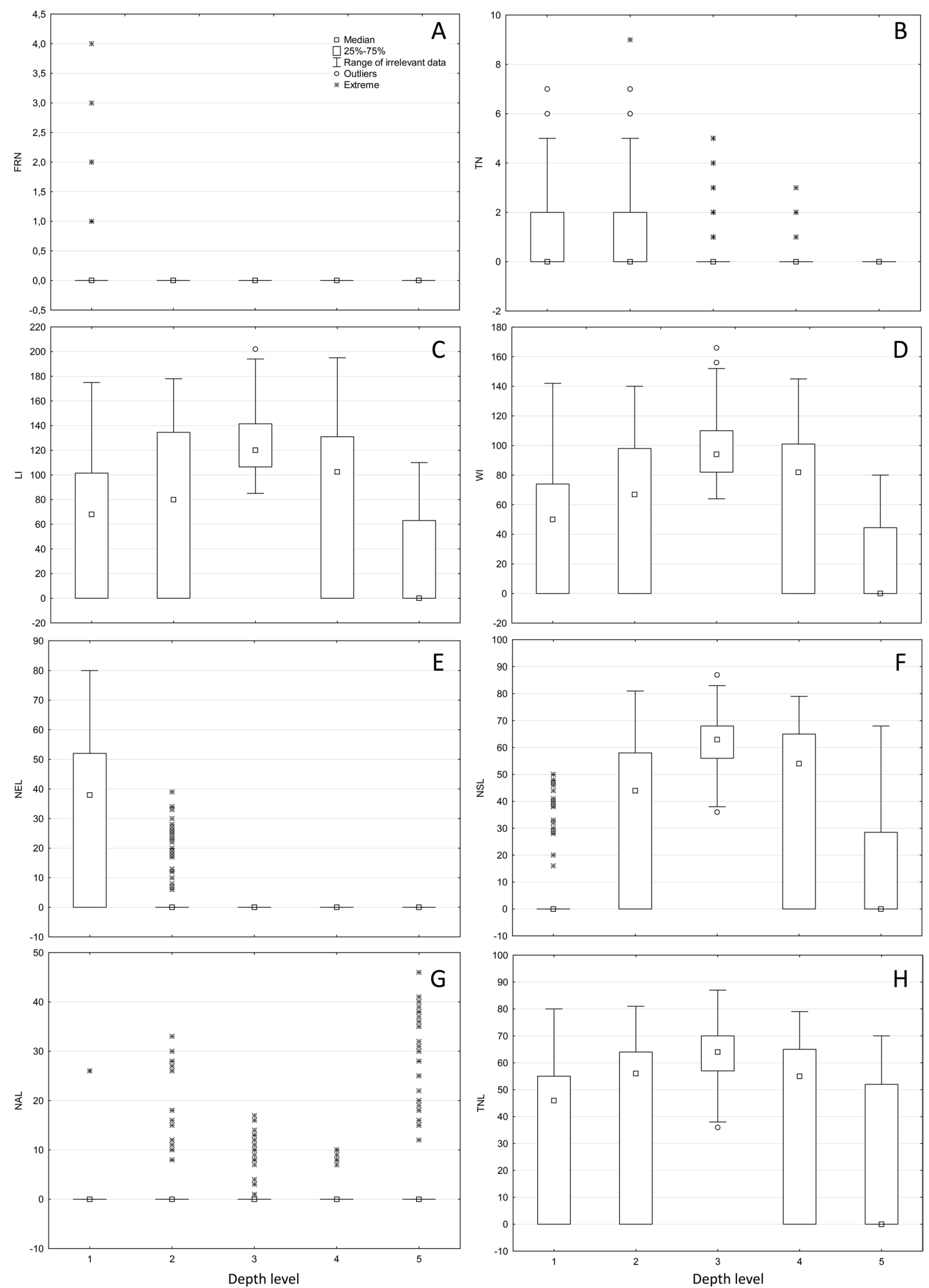

Figure 2 Box plots for 8 features on different depth levels in 6 lakes. A - FRN (number of fruits); B - TN (number of turions); C - LI (lenght of individuals, $\mathrm{cm}$ ); D - WI (width of individuals, $\mathrm{cm}$ ); E - NEL (nuber of emergent leaves); F - NSL (number of underwater leaves); G - NAL (number of arched underwater leaves); H - TNL (total number of leaves) 

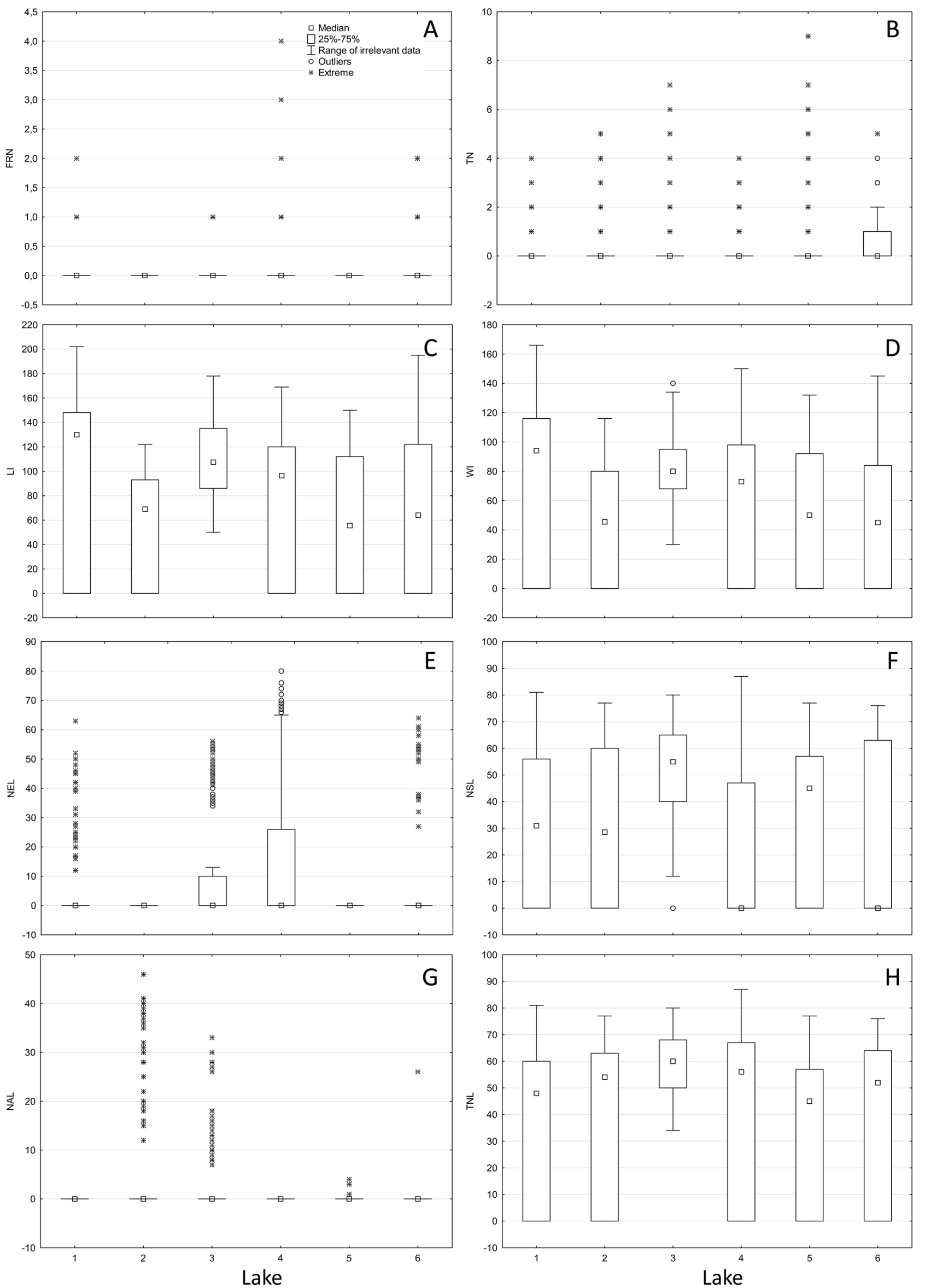

Figure 3 Box plots for 8 features in different lakes. A - FRN (number of fruits); B - TN (number of turions); C - LI (lenght of individuals, $\mathrm{cm}$ ); D - WI (width of individuals, cm); E - NEL (nuber of emergent leaves); F - NSL (number of underwater leaves); G - NAL (number of arched underwater leaves); H - TNL (total number of leaves) 


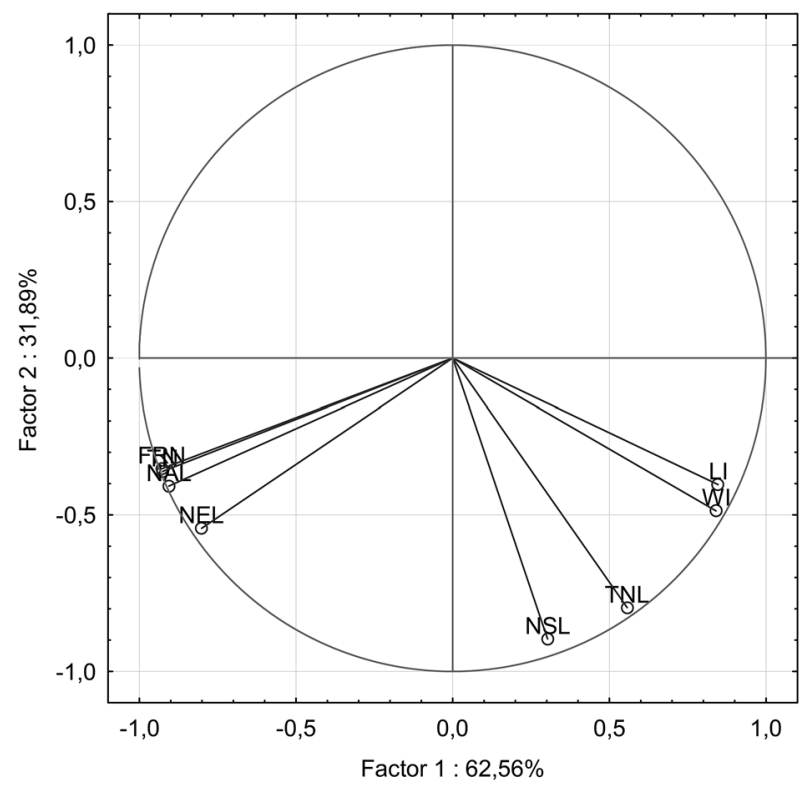

Figure 4 PCA analysis for traits of Stratiotes aloides L. Abbreviations: FRN - number of fruits, TN - number of turions, LI - lenght of individuals, WI - width of individuals, NEL - nuber of emergent leaves, NSL - number of underwater leaves, NAL - number of arched underwater leaves, TNL - total number of leaves

Vectors representing the original variables reach the edges of the circle, therefore all of them are very well represented by the first two primary components and they are all responsible for the high plasticity of Stratiotes aloides. The angle between the vector representing the number of emergent leaves NEL, the number of fruit FRN, the number of turions TN and the number of arched leaves NAL is small, which means a high correlation of those variables. The correlation of those variables with the components forming the system is negative. The vector arrangements prove that they form a uniform group, which is represented by the first component. A different direction is indicated by the vectors concerning the length $\mathrm{LI}$ and width of specimen WI, the number of submerged leaves NSL and the total number of leaves TNL. The angle between TNL, NEL, NSL, FRN with TN is close to 90 degrees, which proves the small degree of correlation. The correlation of vectors of specimen's length LI, width WI and the total number of leaves TNL with the first component is positive and high, and the number of submerged leaves NSL is positive and low. The correlation of the vector of the specimen's length LI and the specimen's width WI with the second component is negative and low, and TNL and NSL is negative and high. This means that variables NSL and TNL are well represented by the second component.

The analysis of the coefficients of variation for the entire database was also performed, where depth was the grouping variable. The analysis demonstrated that the coefficients of variation are the smallest at level 3, that is at the depth of 1-2 meters (Table 3). Each decrease or increase in depth by $S$. aloides specimens results in the effect of an increase in the coefficient of variation. This means that at any depth level other than level 3 there is an increase in diversity of this plant.
Table 3. Average coefficients of variation on 1 to 5 levels from six lakes. Ábbreviations: LI - lenght of individuals, WI - width of individuals, NEL - nuber of emergent leaves, NSL - number of underwater leaves, NAL - number of arched underwater leaves, TNL - total number of leaves. Level 3 bold - the smallest variation.

\begin{tabular}{ccccccc}
\hline \multirow{2}{*}{$\begin{array}{c}\text { Depth } \\
\text { level }\end{array}$} & LI & WI & NEL & NSL & NAL & TNL \\
\cline { 2 - 7 } & 82.71 & 84.07 & 80.60 & 292.84 & 1341.64 & 74.92 \\
2 & 82.22 & 79.75 & 197.77 & 77.81 & 391.71 & 73.27 \\
3 & $\mathbf{2 1 . 7 5}$ & $\mathbf{2 2 . 0 3}$ & 0 & $\mathbf{1 5 . 7 2}$ & 285.66 & $\mathbf{1 5 . 4 4}$ \\
4 & 75.56 & 75.28 & 0 & 73.75 & 671.03 & 73.66 \\
5 & 146.45 & 148.01 & 0 & 154.30 & $\mathbf{2 3 9 . 4 5}$ & 143.63 \\
\hline
\end{tabular}

\section{DISCUSSION}

S. aloides forms submerged and emergent leaves adapting to the aquatic or air environment, changing its reproduction strategy at the same time. Specimens with emergent leaves reproduce sexually. It should be noted that it is a dioecious plant and specimens with submerged leaves reproduce asexually via runners and turions. When the water level goes down or $S$. aloides approaches the surface through the growth of roots or a change in the specific gravity of entire specimens (Kornatowski 1976, 1979, 1983/84), the plant adapts to the air environment by forming rigid emergent leaves. Access to light is of significant importance in the formation of transitional forms (at level 2) with emergent and submerged leaves. The shallower it is, the better access to light and the better formation of emergent forms, whose seeds ensure the survival of the species in the longer term. The germination of seeds of $S$. aloides occurred under laboratory conditions after 3 years (Toma 2000). Such a strategy makes it possible for the plant to control lakes and water bodies in two manners.

In Ranunculus aquatilis L. the change of the form of leaves depends on temperature and photoperiod, and not directly on the water level (Cook 1963). In the case of our research on $S$. aloides, it is difficult to assess the impact of temperature and it was not examined. It is worth noting that the examined specimens grew in slightly eutrophic lakes, which quite recently had been still oligotrophic lakes. These lakes are deep, and their water circulation is different than in small and shallow water reservoirs. However, the heating of water in the littoral surface layers during a hot summer may be significant, which may be of importance for leaf formation. Nevertheless, given the diversity of the locations of multiplicity of $S$. aloides plants (creeks surrounded by trees, places exposed to stronger waves, lakes with higher or lower exposure coefficient, characterised by diverse dynamics of water mixing; lakes with lesser or greater water trophic regime), in the obtained result, the temperature and other factors are some of the variables having impact on the final effect of $S$. aloides plasticity.

No competition between $S$. aloides and other macrophytes were observed in the conducted research. Therefore, in this case, we cannot take into account the impact of other water vascular plants, as in the case of Pistia stratiotes L. and Eichhornia crassipes (Mart.) Solms (Gay 1960, Little 1966, Gopal \& Goel 1993). However, there are reports on competition between phytoplankton and a submerged form of S. aloides for nutrients (Brammer 1979). 
The occurrence of small algae also has impact on access to light in an aquatic environment, as it may be reduced for submerged $S$. aloides plants. There were $S$. aloides plants observed in the lakes of the Kujawsko-Pomorskie region that failed to produce emergent leaves, even when they were $10-20 \mathrm{~cm}$ under the water surface. The water surface in this case, however, was completely covered with algae which formed a 2-3 mm light-proof filter. Light and water depth are two of the predominant factors determining survival, growth, distribution and abundance of aquatic plants. Although many studies have been carried out on the effects of water level and light on plant performance, their potential interactions are poorly understood (Thouvenot et al 2013).

Some authors argue that water level fluctuation may potentially increase the vegetative spread of submerged macrophyte communities and managing water level fluctuation may be helpful for the restoration of submerged macrophyte communities in degraded wetlands (Wang et al 2016). Undoubtedly, water level and the depth of $S$. aloides plants immersion are of importance for the plants' reproduction.

Phenotypic variation is a valuable adaptation mechanism for seagrass species. They emphasised the importance of research on phenotypic variation and lack of research on the significance of in-species phenotypic variation in relation to gradients in environmental conditions on a large spatial scale (McDonald et al 2016). The lack of research on $S$. aloides on a broader scale, concerning phenotypic variation can be also noted. A special case of plasticity is represented by heterophylly, the ability of semi-aquatic plants to produce different types of leaves below and above water.

Submerged leaves are thin and lack both a cuticle and stomata, whereas aerial leaves are thicker, cutinised and bear stomata. The striking variability in the submerged, floating and aerial leaves of heterophyllous aquatics has historically been considered a paradigmatic example of adaptive phenotypic plasticity (Wells \& Pigliucci 2000).

It is important to identify plant functional traits in which plasticity may play a determinant role in plant response to global change as well as on the ecological consequences at an ecosystem level for the competition between wild and invasive species, considering that species with a greater adaptive plasticity may be more likely to survive in novel environmental conditions (Gratani 2014). Plasticity promotes evolutionary diversification if the produced phenotypes provide adaptive diversity that under selection becomes evolutionarily fixed (Pigliucci \& Murren 2003).

S. aloides is also an invasive plant. Invasive species provide an interesting opportunity to examine the importance of adaptive plasticity, e.g., whether adaptive plasticity is the key to a successful invasion (Nicotra \& Davidson 2010). Furthermore, invasive species provide a case study to examine how and how rapidly adaptive plasticity changes following invasion. Such research conducted on the area of prevailing invasion, e.g., in Canada, would be interesting compared to the $S$. aloides plasticity determined in Poland, where it is not an invasive plant.

Alternative forms of leaves in plants are known not only in case of $S$. aloides but also in Ranunculus flammula L. (Cook et al 1968) or Sagittaria sagittifolia L. and Nymphae alba
L. (Arber 2010). Leaf plasticity was also subject to research in the British Potamogeton and its hybrids (Claphan et al 1962), and in Ranunculus, where the nature of leaf variation is under genetic control and may have selective advantage (Bradshow 1965). However, the scope of plasticity of leaves in $S$. aloides is significantly larger than changes in the shape of leaf blades in R. flammula, or the leaf variation in the listed species. In $S$. aloides, plasticity concerns the adaptation of leaves to two different environments: aquatic and air, in combination with the change in the morphological and anatomic structure, and the occurrence of rigid emergent, undulated submerged or arched submerged leaves. This plasticity may have a different nature than a change in leaf blades in the listed species.

The definition of phenotypic plasticity: the ability of an organism to react to environmental input with a charge in form, state, movement, or rate of activity. The variation of plasticity definitions is presented by West-Eberhard (2003). The sources of phenotypic novelty may be different. One of them is hybridisation in Delphinium L., producing novel flower and leaf phenotypes (Lewin \& Epling 1959) and the other, a change in the number of chromosomes (polyploidy) (Grant 1963).

Research on $S$. aloides conducted in Finland confirmed the occurrence of emergent and submerged leaves (Toma 2012). Adaptive changes of this plant do not concern geographical variety, described by West-Eberhard as being confused with alternative phenotypes from different zones (West-Eberhard 2005). There are also different plasticity aspects described with respect to in-generation plasticity and cross generation plasticity (Auge et al 2017).

Conducted research applies to the in-generation plasticity of $S$. aloides, which is constant plasticity and not the creation of only 3 ecophenes described by Kornatowki (1985), or the description of two emergent and submerged forms of S. aloides (Toma 2006). This is confirmed by the presence of transitional form specimens with a different percentage share of emergent, submerged and arched leaves.

The diversity of water soldiers is related to their adaptation to changeable conditions of lighting and water level, as was mentioned before. Light shortage, from a certain level, is a stressful factor for $S$. aloides, which results in the occurrence of submerged leaves, which in turn may prove the existence of genes responsible for the creation of submerged, significantly thinner, less rigid and undulated leaves. Nevertheless, it should be noted that in transitional form specimens of $S$. aloides, there are emergent and submerged leaves at the same time. Determination of whether there is a change in genes during the formation of different types of leaves requires finding out its mechanism and further research at population level, taking into account the dioecy of this plant. The occurrence of different types of leaves in the examined $S$. aloides was demonstrated, as well as their variation in different lakes.

Determination of the depth at which emergent leaves are formed in S. aloides in the lakes of the Bytowskie Lakeland indicate its capability of forming emergent leaves at a specific light intensity. It was also demonstrated that the smallest coefficients of variation for the examined features 
occur at the third level, i.e. at a depth of 1-2 meters. Each change in depth "up" or "down" results in an increase in the value of coefficients of variation of examined features. The occurrence of $S$. aloides at a specified level appears to be optimal. At this level, $S$. aloides also retains the capability of forming stolons and turions, which are forms of vegetative propagation.

\section{CONCLUSION}

Conducted research proved a huge diversity of $S$. aloides for all examined features, except the occurence of male plants, the occurence of buds and flowers, which allows for its survival in the changeable conditions of an aquatic environment. A lake depth of $0.5-1 \mathrm{~m}$ was determined to be where emergent leaves are formed in a lake in forms of S. aloides and it adapts to light conditions. Below 1 meter, only submerged leaves are formed. During the research, many transitional forms of $S$. aloides were observed, with a different number of emergent, submerged and arched leaves, which proves high diversity. At the third level, i.e., a lake depth of 1-2 $\mathrm{m}$, the changeability of examined features is the smallest. Diversity in $S$. aloides manifests itself in the morphological structure, the polymorphism of the number of leaves and their structure, and a different level of the organisation of the entire specimen structure. The result of the research may be applicable in the reintroduction of $S$. aloides in certain areas and in preventive actions in the areas where this species is invasive.

\section{ACKNOWLEDGEMENTS}

I would like to thank very much †Prof. dr hab. Stanisław Marek from the Department of Botany, Faculty of Biological Sciences, University of Wroclaw in Wroclaw and †Prof. $\mathrm{dr}$ hab. Karol Latowski from the Department of Taxonomy, Faculty of Biology, Adam Mickiewicz University in Poznań, for inspiring me to research on Stratiotes aloides $\mathrm{L}$.

\section{LITERATURE CITED}

Arber, A. 2010. Water plant: A study of aquatic angiosperms. Cambridge University Press, Cambridge, 436 pp.

Auge, G.A., L.D. Leverett, B.R. Edwards \& K. Donohue 2017. Adjusting phenotypes via within- and cross generational plasticity. New Phytologist 216(2):343-349.

Bradshaw, A.D. 1965. Evolutionary significance of phenotypic plasticity in plants. Advances in Genetics 13:115-155.

Brammer, E.S. 1979. Exclusion of phytoplankton in the proximity of dominant water soldier (Stratiotes aloides). Freshwater Biology 9:233-249.

Clapham, A.B., T.G. Tutin \& E.F. Warburg 1962. Flora of the British Isles. 2nd ed. Cambridge Univ. Press, London and New York, 1318 pp.

Cook, C.D.K. 1963. Studies in Ranunculus subgenus Batrachium (D.C.) A. Gray. 11. General morphological considerations in the taxonomy of the subgenus. Watsonia 5:294-303.

Cook, C.D.K. \& K. Urmi-König 1983. A revision of the genus Stratiotes (Hydrocharitaceae). Aquatic Botany 16:213-249.

Cook, S.A. \& M.P.Johson, 1968. Adaptation to heterogenous environments. I. Variation in heterophylly in Ranunculus flammula L. Evolution 22:496-516.
Efremov, A.N. 2016. Anatomy and morphology of vegetative organs and inflorescence of Stratiotes aloides L. (Hydrocharitaceae). Inland Water Biology 9(1):27-38.

Efremov, A.N. \& B.F. Sviridenko 2008. The ecobiomorph of water soldier Stratiotes aloides L. (Hydrocharitaceae) in the west Siberian part of its range. Inland Water Biology 3:225-230.

Gadella, T.W.J. \& E. Kliphuis 1973. Chromosome numbers of flowering plants in the Netherlands VI. Proceedings of the Koninklijke Nederlandse, Series C 76: 303-311.

Gay, P.A. 1960. Ecological studies of Eichhornia crassipes Solms. in the Sudan. I. Analysis of spread in the Nile. Journal of Ecology 48:183-191.

Glück, H. 1936. Pteridophyten und Phanerogamen unter gleichzeitiger Berücksichtigung der wichtigsten Wasserund sumpfgewächse des ganzen Kontinents von Europe. In: Die Süßwasser Flora Mitteleuropas, (A. Pascher, Hrsg.), S. 486. Gustav Fisher Verlag, Jena.

Grant, V. 1963. The origin of adaptations. Columbia University Press, New York, 606 pp.

Gratani, L. 2014. Plant phenotypic plasticity n response to environmental factors. Advances in Botany. Article ID 208747.

Gopal, B. \& U. Goel 1993. Competition and allelopathy in aquatic plant communities. Botanical Review 59(3):155-207.

Kornatowski, J. 1976. Dynamics of Stratiotes aloides L. development. Polish Archives of Hydrobiology 23(3):365-376.

Kornatowski, J. 1979. Turions and offsets of Stratiotes aloides L. Acta Hydrobiologica 21(2):185-204.

Kornatowski, J. 1983/84. Morphological forms of the water soldier (Stratiotes aloides L.) Acta Hydrobiologica 25/26:145-156.

Kornatowski, J. 1985. Phenological and morphometrical differentiation of water soldier (Stratiotes aloides L.). Acta Hydrobiologica 27:33-47.

Letz, R., A. Uhrikova \& J. Majovsky 1999. Chromosome numbers of several interesting taxa of the flora of Slovakia. Biologia, Bratislava 54(1):43-49.

Lewis, H. \& C. Epling 1959. Delphinium gypsophilum, a diploid species of hybrid origin. Evolution 13:511-525.

Little, E.C.S. 1966. The invasion of man-made lakes by plants. In: Man-made lakes (R.H. Lowe-McConnell, ed.), pp. 75-86, Academic Press, London.

Mądalski, J. 1938. O owocujących okazach Stratiotes aloides L. w Polsce. Acta Societatis Botanicorum Poloniae 15(3): 245-249.

McDonald, A.M., P. Prado, K.L. Heck Jr, J.W. Fourqurean, T.A. Frankovich, K.H. Dunton \& J. Cebrian 2016. Seagrass growth, reproductive and morphological plasticity across environmental gradients over a large spatial scale. Aquatic Botany 134(2016):87-96.

Moczek, A.P. 2015. Developmental plasticity and evolution - quo vadis? Heredity 115:302-305.

Negodi, G. 1929. Reperti anatomici sugli ovari e sulle fruttificazioni spontanee di Stratiotes aloides L. Archivio Botanico per la Sistematica, Fitogeografia e Genetica 5:207-217.

Nicotra, A.B. \& A.M. Davidson 2010. Adaptive phenotypic plasticity and plant water use. Functional Plant Biology 37: 117-127.

Orsenigo, S., R. Gentili, A.J.P. Smolders, A. Efremov, G. Rossi, M.G. Nicola, N.M.G. Ardenghi, S. Citterio \& T. Abeli 
2017. Reintroduction of a dioecious aquatic macrophyte (Stratiotes aloides L.) regionally extinct in the wild. Interesting answers from genetics. Aquatic Conservation: Marine and Freshwater Ecosystems 27:10-23.

Pigliucci, M. \& C.J. Murren 2003. Genetic assimilation and a possible evolutionary paradox: can macroevolution sometimes be so fast as to pass us by? Evolution 57(7): 1455-1464.

Renman, G. 1989. Life history of two clons populations of Stratiotes aloides L. Hydrobiologia 185:211-222.

Schürhoff, P.N. 1926. Die Zytologie der Pflanzen. Verlag F. Enke, Stuttgart, $792 \mathrm{pp}$.

Smoldres, A.J.P., C. Den Hartom \& J.G.M. Roelofs 1995a. Observations of fruiting and seed-set of Stratiotes aloides L. in the Nederlands. Aquatic Botany 51:259-268.

Smoldres, A.J.P., C. Den Hartom \& J.G.M. Roelofs 1995b. Germination and seedling development in Stratiotes aloides L. Aquatic Botany 51:269-279.

Snyder, E., A. Francis \& S.J. Darbyshire 2016. Biology of invasive alien plant in Canada. 13. Stratiotes aloides L. Canadian Journal of Plant Science 96:225-242.

Strzałek, M. 2004. Zielony wojownik w natarciu, czyli osoka w ekosystemach wodnych. Wiadomosci Ekologiczne 1(2): 83-105.

Sultan, S.E. 2004. Promising directions in plant phenotypic plasticity. Perspectives in Plant Ecology, Evolution and Systematics 6(4):227-233.

Swearingen, J. \& C. Bargeron 2016. Invasive Plant Atlas of the United States. University of Georgia Center for Invasive Species and Ecosystem Health. http:/ / www.invasiveplantatlas. org/ Last accessed 01.05.2017.
Thouvenot, L., G. Thiebaut \& J. Haury 2013. Seasonal plasticity of Ludwigia grandiflora under light and water depth gradients: An outdoor mecocosm experiment. Flora 208(7): 430-437.

Toma, C. 2000. Wpływ temperatury, rodzaju osadów na kiełkowanie nasion Stratiotes aloides L. (unpublished data).

Toma, C. 2001. The development of Stratiotes aloides fruit. In: From Gametes to Embryos. 10th International Conference of Plant Embryology, (J. Salaj, B. Obert and T. Salaj, eds), p. 57. Institute of Scientific and Technical Information for Agriculture Nitra, NOI Publishing, Slovak Republic.

Toma, C. 2006. Distribution and comparison of two morphological forms of Stratiotes aloides L. Biodiversity Research and Conservation 3-4: 251-257.

Toma, C. 2012. Reproduction of Stratiotes aloides in Ilmoilanselkä Lake (Finland). Journal of Ecology and Protection of the Coastline. Baltic Coastal Zone 16:103-111.

Wang, M.-Z., Zh.Y. Liu, F.-L. Luo, G.C. Lei \& H.-L. Li 2016. Do amplitudes of water level fluctuations affect the growth and community structure of submerged macrophytes? PLOS ONE 11(1), e0146528.

Wells, C. \& M. Pigliucci 2000. Adaptive phenotypic plasticity: the case of heterophylly in aquatic plants. Perspective in Plant Ecology, Evolution and Systematics 3(1):1-18.

West-Eberhard, M.J. 2003. Developmental plasticity and evolution. Oxford University Press, Oxford, 816 pp.

West-Eberhard, M.J. 2005. Developmental plasticity and the origin of species differences. Colloquium 102 (Suppl.1): 6543-6549. 